\title{
The Use of Masquerade Cult and Umu-Ada Fraternity (Igbo Daughters) for Peace and Conflict Resolution in Eastern Nigeria (Igbo Land)
}

\author{
Dr. Mrs. Louisa Amaechi \\ Directorate of General Studies \\ Federal University of Technology Owerri \\ Imo State- Nigeria
}

\begin{abstract}
There are some cases, social problems and cultural conflicts experienced in most Igbo communities of Eastern Nigeria. Such social issues are cultural discrimination such as outcasts (Osu), slavery (Ohu), obnoxious widowhood practices, communal clashes and land disputes. The crisis, conflicts, clashes, violence, disagreements and wars that usually come up in most of the Igbo communities in Eastern regions were and are still been handled, managed or been resolved through the use of masquerade cult and daughters of the land (Umu-Ada) to render social justice. The paper discussed the concept of masquerade cult and Umu-Ada fraternity (Igbo daughters) in conflict resolution in Eastern Nigeria. The paper examined the socio-political implications of the treatment given to the slaves (Ohu), outcaste (Osu) and widows to the nations development. The paper also discussed the need to revive the use of such traditional institutions for peace and conflict resolution and the challenges confronting them. The paper therefore recommended government sponsorship for the effective functioning of masquerade cult and Umu-Ada (Igbo daughters) for peace and conflict resolution in Nigeria.

Key words: masquerade cult and Igbo daughters' fraternity (Umu-Ada) in conflict resolution, methods of conflict resolution and challenges.
\end{abstract}

\section{Introduction}

Masquerade cult and Umu-Ada fraternity (Igbo-daughters association) are two African traditional cultural concepts that play a vital role for maintaining peace and social justice as well as managing any conflict that erupts in Igbo society in a traditional way more than court way. They are traditional institutions that do not compromise their cultural stand, nor be influenced either by European ideology or government principles. They directly or indirectly attract the spirit world or ancestors, local deities or African science and technology which cannot be modified nor changed as a culture. In Igbo land the masquerade is a powerful cultural entity or being that sometimes appears to stand as a human being that covered himself so that nobody can identify the individual because of the mask while sometimes people believe that it is a spirit that comes from the underworld- the ancestors or dead ones that came to make peace physically. Masquerade cult is a kind of traditional association made up of adult citizens in Igbo-land that take certain secret oaths or have belief and practices which is respected and carried out in the society either for entertainment, peace accord or conflict resolution It is a system in which some qualified members cover themselves from head to toes, beat certain traditional music, drum and exhibit their cultural skills for public consumption. Sometimes, they involve themselves into certain cultural diabolic and ritual acts and practices that make them to appear and disappear from the scene of entertainment places as part of the entertainment act. Some people from different part of Igbo-land in Eastern Region of Nigeria believe that masquerade is a spirit that comes from spiritual world or under the earth surface because of its nature of appearing and disappearing from human existence. As a result of occultic and diabolic display, they insist on social justice, peace and conflict resolution among families, individuals and communities in Igbo land, Nwankwo (2012), Ume (1983), Jone (1949), Ezeanya (1979) and Jinehu (N. dated).

\section{The Concept of Masquerade}

According to advanced oxford learners dictionary 2006:357 "masquerade is part of people's culture. "Culture is the customs and beliefs, art and way of life of social organization of a particular group of a people or country. In another vein, culture is defined as a way of life, life style, customs, habits, ways and moves of people (Macmillan English Dictionary for Advanced Learners 2007:1653). 
Furthermore, it is a principle and believes that influence the behavior and way of life of a particular people. The values that are the basis of a people's identity and their sense of particularity as members of human race (Thionago 2007: 293). Masquerade is an aspect of igbo-culture while culture according to EB Tylor is that complex whole which include the knowledge, art, belief, customs and other capability of life. Among the Igbos, the masquerade is a cultural matrix, a way of life, phenomenal, highly valued and held in differences. Masquerades are of different types. Onyeneke (1987:77) identified what is known as lampooning masks which operates in the night as man-made own. They identify, publicize and ridicule criminals, witches and wizards and other evil men who constitute a threat or nuisance in the community as aspect of masquerade when these types of masquerades persist in their wrong doing they are terminated in the night by the original masquerade who will employ their normal mystical and esoteric measures or processes which contribute to the mysticism of the masquerade institution. Where some masquerades are fierce looking, others stimulate feminine beauty. Some are made to look like white men and play the part of colonial administrative officer for rendering justice in communities. There are some that appear during festivals like new-yam festival in various Igbo land. Some others appear during the veneration of local deities, such as the ones which appear during what is called owu festival, they appear seasonally, but rather enormously unwieldy, "ijele" masquerade of some part of Anambra state is displayed once in two or three years. Usually, masquerades outing is characterized by social justice and entertainment celebrations, festivals and sumptuous fasting. Notably, traditional musical instruments are used to accompany the masquerades such include the wooden slit drum of various sizes, metal gangs, bells, maraca and wooden flutes. The flutist is a very important element in masquerading. Chiefest among his functions is that heedfully communicates with the masquerades with weaving soulful melodies and blending esoteric messages into the intoxicating rhythm of the rums and gongs.

\section{Functions}

As a matter of fact, masquerades have their functions (Okezie 2007:110) says "masquerades are regarded as spirits, hence the enormity of the powers are wield. They are the community conscience, playing the role of the village police. They are used to enforce the controlling traditional authority which the community elders derived from their ancestors", they restore peace and justice in the land. In furtherance, Nwabueze (2003:60) observes that in the ancient Igbo society, "the masquerade performances were intended to accomplish results, the intention of the nature was to communicate their wishes to the ancestors in order to change the state of things" according to him, the Igbos believed in the efficacy and impartiality of the masquerade in peace and conflict resolution. By invoking the masquerade as a final judge. The Igbos believed that they were invoking the ancestor, who was symbolized in the masquerade, hence the demands of the living were clearly communicated to the supernatural forces through the ancestral spirit who, in the case were masquerade.

Again, Nwabueze (p. 3) says that "the masquerade regarded as the final arbiter in serious cases" lending support, Onuekwuzi (2001:160) believes that among the Igbo's "the masquerades were very powerful instruments of government before the advent of colonialism". Christianity and the Western legal system. Even now, among societies where tradition is still strong, these masquerades still enforce the payment of fines for breaking of taboos and refusal to conform to culture related justices. Continuing, Onuekwuai (P 167) observe that "a small type is a celebration of the integrated art forms of the society that produced it as masquerade. He opines that it is an opportunity for the exhibition of expertise in caving and representation of intended motives on wood, dyeing, weaving with rope or raffia, intricate dance steps, elaborate drumming of spectacle. It is worthy of note that the masquerades features in many parts of African as drama. For entertainment in the society as the case may be and for peace and social justice when needs come.

Notably in Africa, drama is found in religious rituals and festivals characterized by masking, role play and mimicry. Ritual on its part involves impersonation whereby the ritualist represents the people making a request and sacrifices to the gods. Ritual is incorporated in festivals and festivals are public celebrations of events regarded as important and of high value by the community. It is the unique nature of African festivals that embody and indeed combine at once several roles, features, and elements that cut across the domain of the artistic, the religious and socio-cultural life of the society. The importance of a festival cannot be over-emphasized as they tell the history of the people in action. They also unify such people and the young of the society are made to know what their society extols or abtors. According to Akporobaro (2006:366) in most societies festivals play very important roles that are linked to the survival of the society. They include: 
- The propitiation of gods, goddesses and spiritual powers.

- The celebration of some post historical event in the life of the community.

- Festivals do also serve as social means of ushering in a period of prosperity and fertility in the life of the community.

- To re-invoke the gods and secure their attention and help towards the protection of the society.

- To empower the people in time of war.

- To provide a contest for merry making for arranging marriages and for whirling the new seasons.

- The purification of the land and for warding off evil forces and to show off the neighbors the power and strength and invulnerability of the community against external threats.

Among the Igbos, many festivals abound, such include the festival of the farming cycle campaign, the new yam festival or the festival of the pumpkin leaves etc. these are celebrated in honour of the God of fertility and farm produce known as Ahiajoku. Again, there is the festival of deity worship and ancestor veneration for example the "okorosha", "owu" and "ikeje". These festivals involve masking in the sense that they involve the dead and as a result, spiritually oriented. Furthermore, there are the festivals of the rites of passage, they include the "iru mgbede" and "iwa akwa" ceremonies. Such festivals mark the transition from puberty to adulthood. It is pertinent to note that the idea of the masquerade is tied to the Igbo concept of ancestor worship. What is being personified in a masquerade is a revered Igbo ancestor invited back to life to commune with the living. The kind of masquerade being presented depends on the function that the masquerade is expected to perform. Hence the masquerade is a medium through which the living Igbos communicate with the living dead. Again masquerades symbolize societal conception of certain qualities, or instance, while the 'agaba' symbolizes strength and masculine vigor, the aggboghommanwu (the maiden masquerade) that usually depicts feminine beauty portrays acceptable qualities of maidens as exemplified in their beautiful outlook, careful gout and dancing ability, Afigbo (1972), Nwabueze (2003).

Apparently, the rate of the masquerade in the life of the Igbos need not be over emphasized. Apart from representing ancestral heroes, the mimetic displays of the masquerades group also express the society's cultural and social belief and discloses what constitutes the ideal in the Igbo society. The Igbo people form one of the three largest ethnic groups residing in Eastern part of Nigeria. Like their neighbors, nationally and internationally, they believe that they belong to the Negro race in Africa and speak a language that belongs to the Kwa group of languages found in West and Central Africa. They speak a language called Igbo. According to the 1963 population census in Nigeria, the Igbo numbered about eight (8) million but currently much more higher than that. Their territory cuts across equatorial forest in the south and the savanna in the north, this territory of Igbo land includes part of Aboh, Asaba and Agbor division in Delta state. In the east, it embraces the whole of Anambra, Imo, Abia, Ebonyi, Enugu, parts of Ogoja in Cross River State, Ahoada and part of Port Harcourt division of River State of Nigeria.

Put in terms longitude and latitude, one can say, that Igbo land is roughly circumscribed between 6 . And $81 / 2$ east longitude and $4 \frac{1 / 2}{2}$ and 71/4. North latitude. The neighbors of the Igbo are the Ijaw and Ogoni in the south and the Benin and Isoko in the west (Arinze 1970 p11). The Igbo traditional society was essentially made up of peasants who depended mostly on subsistence agriculture. Before the advent of the colonial rule in Nigeria, the Igbos had achieved highly developed handicrafts namely, weaving, palm wine making, pottery- making, smiting etc. exchange had also developed up to the point in which long-distance trading which enabled a class of merchants to emerge. The Aro's of Igbo land were famous in such business. The family, village and clan as extensions of blood ties were important unit of social, political and economic organization. The closeness of the people of their natural environment, especially to the social, political and economic organization made them to work hard. The closeness of the people to their natural environment, especially to the soil as well as their closeness to their family and blood relations were reflected in their philosophical, political and religious ideas and organization, (Green 1964:40)

\section{The Unifying Factor}

One significant thing about Igbo traditional societies in the absence of all-embracing social and political system with the result that many writers and investigators have wondered in what degree one could reasonably talk of the Igbos as a unit. Indeed, one of the most striking features about the pre-colonial Igbo society was its apparent social fragmentation with hundreds of small, more or less independent social units, the largest being, in many cases, what we may call the village group (Ofoegbu 1972: 49). 


\section{Causes of Conflict In Eastern Region- Igbo Land.}

There are many issues that can result to serious conflicts. They include Tribalism, resource control, religion culture, land disputes, trade and business disputes. Others are leadership tussle and access to power, right and privileges, belief and tradition, ideological differences, norms and custom of the land. The distribution of wealth can as well cause conflict where the head of family member dies without writing any will for his wealth distribution to his family and relatives, the natural resources like Niger Delta crude oil zone usually generate violence, tension and conflict in the region. This is always noticed where militants like lobbying for the greater share of oil revenue from the federal government because of the exploration that leads to land degradation in their various oil communities. There are certain principles and ideologies that can cause conflict in Eastern region, these are the tradition and belief of outcaste (OSU) system, the slaves (OHU) and widowhood challenge and its associated discrimination, nepotism, accusation, allegations of neglect in the society, oppression, domination and exploitation, victimization, bigotry and marginalization. Uwazie (2000), Birgit (2001), Heitler (2011) and Fred (2008).

\section{The Concept of Conflict}

The word conflict is derived from the Latin word "confligere", meaning "to strike together". Conflict therefore means to strike or to clash. A flight to disagree, struggle or battle, clash, contention, confrontation, a controversy or quarrel, active opposition, strife or incompatibility to meet in opposition or hostility to contend, contrary or to be variance. Conflict also means contradiction arising from differences in interests, ideas, ideologies or principles, culture orientations, beliefs perceptions and tendencies. Best (2005), Francis (2007) and Batubo (2010). Conflict is a normal natural inevitable phenomenon in any interactive inevitable phenomenon in any interactive situation of human life, contradictions exists at all levels of the society-intra psychic, personal, interpersonal, intra-groups, inter-group, institution, international and intra-national issue, (Burton 1990), Maihi and Wood (2001), Idowu (1999). Conflict sometimes is a by-product of social change and may lead to constructive transformation in the society especially Africa. Conflict is any situation in which incompatible goals, attitudes, emotions or behaviors that can lead to disagreement or opposition between two or more parties exists, Daniel (2016)

Conflict can as well be defined as a type of behavior which occurs when two or more parties are in a serious opposition or in battle, as a result of a perceived relative deprivation from the activities of or interacting with person or group, Best (2005). Conflict resolution in itself is a formal statement of an opinion agreed on by a committee, individual, state or a council, by the means of dialogue or vote, Daniel (2016).

Resolution is a collaborative problem solving, a cooperative taking together process that leads to choosing a plan of action that both can feel good about, Maihi and Wood (2001), Fred-Mensah (2008). Peace is essential for any meaningful development to take place, production and industrial activities can only exist in any enabling environment, in Nigeria today, many conflict and challenges that is threatening the existing of unity is on bond, it includes, political violence, insurgency (Boko Haram) by the Muslim brothers in the north, communal clashes, activities of the Hausa-Fulani herds men in agric farmland, kidnapping and the Niger Delta activities and disturbances in the crude oil producing communities. Finally, the general social insecurity that make communities to suspect each other and the maritime insecurity among others. Birgit (2001) and Best (2005). There is the need to have Karl Marx conflict theory ideology that states; that society is a state of perpetual conflict due to competition for limited resources. It holds that social order is only maintained by domination and power rather than consensus and conformity. To Kart Marx, conflict is therefore be defined as those with wealth and power who try to hold onto it by means possible, chiefly by suppressing the poor and powerless in order words social injustice that needs to be corrected through conflict resolution, Daniel 2016, Otite (1999).

\section{Causes of Conflict}

There are some other causes of conflict in Igbo land, the human rights abuses and practices of widow-hood where intimidation, social injustice and abuse of power is unleashed on widows, sometimes widows are subdued not to fake their birth for twenty- one days or more after the death of the husband or to drink the dirty water which was used to bath the diseased husband can cause a serious conflict between the relatives of the women and the husbands relatives. Other dimensions of causes of conflict have been identified by some writers which include lack of sense of community and belongingness to such community. Lack of sense of belonging is a feeling that members matter to one another and to the group, and a shared faith that members needs will be made or met through their commitment to be together. 
Lack of this sense of belongingness is the only purpose of taking a great part in destruction of lives and properties in the land. This is part of indoctrination and misinformation which people always keep in their minds and keep rigid in their beliefs and stories given to them by some of their elders that felt maltreated in the community. This belief system of some people reflects on the way they think, act, feel and behave in the society towards others. Opinions are often based on beliefs which can have an uneasy relationship with facts. Beliefs do dictate the facts people chose to accept, wrong information which can be uncritically accepted, just because it reinforces the beliefs. The reinforcement makes us more confident to be right, and even less likely to listen to new information. This further explains why people cannot think in more positive terms as in the case of insurgency otherwise called (Boko Haram) in the far north of Nigeria. Insurgency does not fear human face and does not respect human rights and rule of law. Those who believe in it see themselves as members of a particular group conforming to the standards of the group leading to involvement in various activities that are unacceptable either by law or norms of the land, and are out to destroy any one who does not comply with their demands.

Human social life would simply not be possible without social identification; we should be able to know who they are and who others are, collective identities are inherent in social life, whether part of a conflict or not. When and how identities contribute to intractable conflicts depends greatly on the content of the identities held. Certain qualities of identities contribute significantly to the intractability of conflicts, and whether those conflicts are constructive or destructive. Identity problem is not only a national problem, it is and will remain for decades to come the most important source of international violence and war in the world. Identities conflict is built on the belief of group members.

What it means to be a group member and typically, who the groups enemies are. The beliefs of group members are easily discernable in the national media, school curricula, official government documents and speeches, popular literature and history etc. the more hostile the belief or ideology, the more likely violence occur, and the more severe it is likely to be. Identity is used in connection with personal individuality. It has to do with selfhood, self actualization, freedom and authenticity, life style which involves everything from subculture to social position and social status. For the proper inculcation of the right social values and tolerance, the process of losing identity must be reversed and identity restored. Some other causes of conflict in Igbo land are struggle for supremacy of power, selfish interests, social change, individual differences, educational differences, land disputes and clash of interest groups in the society.

\section{Conflict Resolution}

Conflict resolution is conceptualized as the methods and process as involved in facilitating the peaceful ending of conflict and retribution. It can as well be a committed group members attempt to resolve conflict or group conflicts by actively communicating information about their conflicting motives or ideologies to the rest of the groups and by engaging in collective negotiation (Ibeanu 2006). This can be done through negotiation and creative peace building. In another development Miller (2003) and Best (2005) see conflict resolution as a variety of approaches aimed at terminating conflict through the constructive solving of problems, distinct from management or transformation of conflict. It is expected that deep rooted sources of conflict are addressed and resolved and behavior is no longer violent, nor are attitude hostile any longer. Mai and Wood (2001); while structure of the conflict has been changed. Mitchel and Banks (1996) opted that conflict is bad hence it is something that should not be encouraged. It is also assumed that conflict is a short term phenomenon that can be resolved permanently through mediation or other intervention process. Best (2005 P40) puts everything together saying that conflict is resolved when the basic needs of parties involved have been met with necessary satisfiers and their fears solved. In principle, conflict resolution connotes a sense of finally where the parties to a conflict are mutually satisfied with the outcome of the settlement and the conflicts resolved in a true sense of it.

\section{Method of Conflict Resolution by the Masquerade}

In the case of land disputes or communal clashes, masquerade will surround the disputable environment, bound people not to cross nor penetrate into the environment for some period. Sometimes, palm front will be tied at the disputable environment, warning people not to make use of the place. The masquerades will later invite the people concerned who are involved in the matter, listen to their various grievances after interviewing or questioning them as mediator. Whoever that is at fault will pay penalty for defaulting or punished accordingly to restore peace. 
In the case of social injustice for the outcaste (Osu) or slaves (Ohu) and widows who are denied of free movement, interaction or right to personal or husband property or abuse of their other rights in the society, the masquerades or the daughters of the land will handle the case effectively to avoid social injustice. Whenever masquerades intervenes in any case and finds defaulter, it kills any available animal around ranging from fowl, chicken, goat or cow and compel the defaulter to pay to the owner of such animals as punishment likewise the daughters of the land (Umu-Ada Fraternity).

The issue of widows being compelled to drink the waste water which is used to wash the corpse of the husband is a human right abuse which the daughters of the land usually intervene and handle the matter to avoid health problem and the widow not been infected is always the duty performed by the masquerades and daughters (Umu$\mathrm{Ada})$. The slaves $(\mathrm{Ohu})$ and the outcaste (Osu) are not allowed to interact freely with the free born nor to inter marry with them, the masquerades and the daughters (Umu-Ada) always intervene to arrest the ugly situation and bring justice to the land. Both masquerades and the daughters of Igbo land (Umu-Ada) play very vital roles in social justice and peace and conflict resolution in anywhere in Eastern Nigeria (Igbo land).

\section{The Socio-political Implications of the Treatment of the Slaves (Ohu), Outcaste (Osu) and Widows to the National Building.}

The slaves $(\mathrm{Ohu})$, outcaste $(\mathrm{Osu})$ and the widows receive undesirable treatment in Igbo land and are always treated as second class citizens or rejected and dejected people in the society who should not enjoy freedom of association and rights like the so called free born. The resultant effects of this establishment of schools and industries in other countries by these hardworking industrious and highly educated group of people who go extra miles in all areas of their life to improve their economy and distinguish themselves in the society. Politically, most of these groups of people improve their educational standard and are the people who suppose to manage the government of the country effectively without minding the ethnic sentiments but are never allowed to be voted into power because of the societal discrimination. Nationally, and state wise these people who are not regarded as free born citizens tend to have better character and may have corruption free practices in governance if given opportunity to rule the nation. Most often, they leave their communities, states and nation to a farm land where such discrimination will not affect their psychological feeling to be established. They have fear of God more than these so called free born because they were the first group of Igbo people that embraced Christianity and followed the European way of life. Most of them are the great scientist and technologist who went to Europe and America and refused to come back home because of the abuses at home. Most of the slaves, outcaste and widows are gifted in hand work and talented in skill acquisition; they are good in soap making, hotel management, bag and shoe making, agricultural production and bread baking. They are also good in hair dressing, moulding, building technology, acquire cultural production like fishery services, welding work, carpentry work and industries in other entrepreneurial development that can boost the economy of the nation but unfortunately, these industrious citizens of Igbo land do not make these establishments in their homes but go to other states and nations to develop them due to the stigma of slaves $(\mathrm{Ohu})$ and outcastes (Osu) which is attached to their personality. Unfortunately, their psychological philosophical, emotional, physiological and biological gift and talent which should be useful to the development of the land is diverted to others.

\section{The Need for Peace and Conflict Resolution in Nigeria}

Nigeria is a country which is made up of different ethnic groups with different religious, cultural and ideology principles. The country has experienced different inter-tribal wars, political violence, religious and economic wars and need to have a second thought of having absolute peace in order to achieve any meaningful development.

Communal clashes and the activities of the Hausa/Fulani herdsmen in their recent killings of the farmers and destruction of agric farms, if not checked cannot allow any economic growth. Peace and conflict resolution will go a long way to save the country from disintegration ideology that is fast approaching if well addressed, it will as well go to some extent to check the rate of structural and cultural violence which the nation is passing through on yearly basis. It will create the opportunity to reduce the rate of poverty and social inequality in the country.

\section{Challenges}

The traditional use of masquerades cult and Umu-Ada association for peace and conflict resolution is seen by the members of different communities recently conflicts that is highly diabolic and unhealthy for peoples consumption, as a result people do not respect such command again when they are called or invited by the two traditional institutions for any problem solving. 
Presently, in Eastern region of Igbo-land in Nigeria, civilization, modernization, western education and introduction of science and technology has opened the eye of many people who now decide to go to court for litigation for settlement of disputes, individually or by community members thereby neglecting the role of masquerade cult and Umu-Ada (daughters association as the major traditional institutions for peace and conflict resolution. The introduction of western religion had made many Igbo communities to understand that, there is power that is greater than the masquerade power which always lead to the resistance of its power and authority in people and communities. In recent times, also due to bribery taken by the judges and lawyers in the law court, people decide to go to their traditional institution especially for social justice that will favour them because masquerades and Umu-Ada do not take any form of bribe before rendering any social justice.

Lack of fund and recognition by the government is a big challenge to sustain their existence and roles they play in recent times. In some communities recently, the high level of education obtained by some members of such association makes them to shy away from carrying out their duties and functions as traditional institutions for peace and social justice in the land because they see it to be primitive in nature and need to be encouraged.

Most often, the diabolic and occultic nature in the society scare people away from patronizing them for peace and conflict resolution because sometimes they resort to diabolic means for effective justice. Consequences/ social implications of cultural practices of social injustice given to the slaves (Ohu), out caste (Osu) and widowhood practices are enormous in Igbo land. Culturally, the slaves and outcaste are not given equal treatment as normal human beings. There are always human rights abuses among them in any Igbo society where they exist. They are always isolated in the society; they are not allowed to marry the free born (Diala) in the society. They are not allowed to share the communal land or other properties along with the free born. They are not allowed to head a clan, village or kindred even when they are the most educated, oldest or wisest in the community. They are seen as forbidden people. They are not always allowed or advised to context for any political post in their communities. They are seen as second class citizens in any environment where they are found. They are always given names that portray what they are in the society. Sometimes, they are forbidden not to interact or integrate meaningfully with the free born in the society, or exchange greetings or host meeting in their environment. Inter marriage system is totally forbidden with the free-born. Their buying and selling system within their community is equally affected by their scourge. These discriminative measure given to such slaves and outcaste in the society usually result to exhibition of some social problems such as aggressiveness, armed robbery, drug abuse, embarking upon communal clashes between the free born communities and the outcaste or slaves dominated environment. It can as well lead to unnecessary killing and murder of innocent souls, raping, kidnapping, ritual killing.

\section{Conclusion}

The socio-cultural problems of social injustice such as outcaste problem, popularly called (Osu), the slave trade issue known as (Ohu), communal clashes, unnecessary shading of innocent blood in the community, false accusation, kidnapping and use of African science and technology i.e. (charms) in inflicting injury and illness in the life of some innocent Nigerian citizens is rampant in African society.

The European method of rendering justice through the use of court such as high court, Appeal court, customary court, supreme court and others have failed in rendering justice in Nigeria. This is because of the corrupt practices attached to it in Nigerian society. Court that supposed to be the last hope for a common man turned to be the hope of the wealthy people in the society who can afford to get or hire intelligent, well to do and capable lawyers who can defend the rich man at the detriment of the innocent poor people who cannot afford to hire good lawyers.

In this vein, the services of the village masquerade and Umu-Ada Fraternity as a social force of culture which does not consider anybody's wealth, height, possession, academic attainment or position in the society while rendering their services come in. these two important social cultural institutions in Igbo land which is in Eastern part of Nigeria in Africa plays very vital roles in rendering justice and maintaining law, order and peace in African society were respected so much in Igbo land during the precolonial era in Africa. In a situation where innocent citizens are jailed, detained or killed as a result of either false accusation or their inability to hire a good lawyer to defend them in court becomes rampant in Nigeria, it is worthy of note to go back to the issue of using masquerade and Umu-Ada for a fair justice in Nigeria. The use of masquerade cults and Umu-Ada association in fostering peace and maintenance of social justice in Eastern Nigeria has helped a lot in sanitizing the society, reduces the unnecessary shading of innocent blood in different communities. Eradicates the cultural habits of maltreating the widow in Igbo land. 
It brings peace, peaceful co-existence of different people in their various communities and environments, Onyeneke (1987), Nwabueze (2003) and Afigbo (1971). It has helped to address the societal segregations between the free born and the slaves $(\mathrm{Ohu})$ or outcaste (Osu) in Igbo society and needs to be encouraged or empowered by the Nigerian government most especially in reducing the suffering of the Igbo widows.

\section{Recommendation}

There should be equal opportunity for every human being in every society, there should also be equal treatment, freedom of speech, expression and rights irrespective of the societal cultural attachments in Igbo land.

Traditional institutions should use masquerade and Umu-Ada (Igbo daughters) should be encouraged by government to handle sensitive matters in rural communities.

\section{References}

Afigbo, A.E. The Indigenous Political Systems Of Igbo. An Unpublished Material.

Afigbo, A.E (1971). The Igbo Under British Rule' The Conch- Special Edition on Igbo Traditional Life and Literature Vol 111 No 2

Aranze, F (1970) Sacrifice in Igbo Religion, Ibadan University Press. Ibadan.

Batubo F.B (2010). The Role of Library in Conflict Resolution; The Niger Delta Case.

Ben Porah, S.R (2003) "War and Peace Education in Journal of Philosophy of Education Vol 37 No 3 Pp 525

Best, S.G (2005) Introduction to Peace and Conflict Studies in West Africa. A Reader (Ed) Ibadan: Spectrum Books Ltd.

Birgit Brock- Utne (2001). The Indigenous Conflict Resolution in Africa. Retrieved 25 ${ }^{\text {th }}$ Sept 2016 Feon Htt://Www. African Venir Paper/Brockutne Traditional Resolution Pdf.

Burton J.W (1990), Conflict Resolution and Prevention. London: Macmillan.

Daniel, .G (2016) Conflict Resolution a Veritable Instrument for National Development in Nigeria (An Unpublished Materials).

Emeyonu .O And Ali E (1985) Culture and Development, in Africa. New York PWPA.

Erickson, M. (2001) Reconciliation and the Search for a Shared Moral Landscope in J.R Cocharane, (Ed) Journal of Theology for Southern Africa (Pp 19-42) Cape Town: Atla.

Ezeanya, S.N (1979) The Osu system in Igbo Land: Journal of Religion in Africa: Leinden .L

Ezike, ojiaku (n. dated) Center for Igbo Studies, Imo State University, Owerri, Nigeria.

Francis, D.J (2007) Peace and Conflict Studies: An African Overview of Basic Concepts. In Introduction to Peace and Conflict Studies in West Africa: A Reader Best Sg (Ed) Ibadan: Spectrum Books.

Fred- Mensah, B.K (2008) African Conflict "Medicine" An Emerging Paradigm Shit in African Conflict Resolution? In Terrence Lyons and Gilbert M (Ed) Conflict Management and African Politics: Ripeness Bargaining and Mediation, London: Routledge, 136-144.

Green, M.M (1960), Igbo Village Affairs, London, Frank Cass \& Co.

Heitler .S (2011) Communication, Listening and Conflict Resolution Skill. The Encyclopedia of Peace Psychology (Ed) Balckwell Publishing.

Ibeanu .O (2006) Conceptualization Peace; Peace in Best S.G (Ed) Introduction to Peace and Content Studies in West Africa Ibadan: Spectrum Books Ltd.

Idowu, W.O.O (1999) Citizenship, Alienation and Conflict in Nigeria. Africa Development, Vol 24 No 152 Pp 33-34.

Jinehu, E.U (n. dated) The Osu Caste in our Society. Tudor and Group Printers, Enugu.

Jones, G.I (1949) Dual Organization of Igbo Social Structure Africa. Vol 19 No 2

Lederach J.P (1977). Building Peace Sustainable Reconciliation in Dividend Societies, Washinton D.C. United State Institute of Peace.

Lederach J.P (1995). Preparing for Peace: Conflict Transformation across Cultures: New york Syracuse University Press.

Liayd, Thompson of C.O Uroh (1996). Africa in the Philosophy of Culture: Demystifying an Ideology of Cultural Imperialism, Journal of Philosophy and Development. Vol 2 No 112.

Macmillian English Dictionary (2007) Oxford: Macmillian Publisher.

Maihi, H and Wood House, T (Eds) (2001) Contemporary Conflict Resolutions, the Prevention, Management and Transformation of Deadly Conflict. Cambridge Polity Press. 
Nkwo, M. (1984), Igbo Cultural Heritage, Longman.

Nwabueze, E. (2003). "Igbo Masquerade Drama and the Problem of Alien Intervention: Transition From cult to Theater" In Visions and Revisions: Selected Discourses on Literary Criticism, ABC Publishers Enugu.

Nwankwo, Obc (2012) General Studies in Arts: Some Fundamental Topic: Credibility in Crisis Management and Conflict Resolution, the Key to Communal Peace and Development Pp 148- 150 Rajah Dynamis Ltd. Illorin.

Ofoegbu, R.M (1972). Who are the Igbos? The Renaissance Sept. 18 No 68.Ogbalu, F.C (n. dated) Igbo Institution and customs. UPC, Onitsha.

Onwuejeogwu, M.A (1972) Odinani: The Journal of Odinani Museum Nri Vol 1 No 1 March 1972 P. 40.

Onyeneke, A.O (1987) The Dead Among the Living Masquerade in Igbo Society; Nimo Niger: Holy Ghost Congregation, Province Of Nigeria And Aselet Institution.

Otite, O and Albert, O.I (1999) Community Conflicts in Nigeria. Ibadan; Spectrum Books.

Oxford Advanced Learners Dictionary (2006) Oxford Publishers.

Talbot, P.A (1969). The People of Southern Nigeria. Great Russet Street, London WCL.

The Conch, C. (1971) Igbo Traditional Life, Culture and Literature Sociological Journal of African Cultures and Literature Vol 111 No 2 Sept 1971.

Thiango, N (2007). "The Language of African Literature in African Literature. An Anthology of Criticism and Theory. Olaniyam, T. And Quayson A. (Eds). Blackwell Publisher U.S.A

Tylor, E.B (1924) Primitive culture, New York - Bentano press.

Uchendu, V.C (1967) The Igbo of Sourthern Eastern Nigeria: case of cultural Anthropology: standard university.

Ume I.O (1983). The basis of inequality in Igbo society, a paper read at SPILC Seminar at UNN, September 8-10

Uwazie, E (2000). Social Relations and Peace Keeping among the Igbo, in Willian 2 (Ed) Traditional Cures for Modern Conflicts: African Medicine Ppiso. London: Rienner Publishers. 